\title{
Immunopathology of Chagas Disease
}

\author{
Zilton A Andrade
}

Laboratório de Patologia Experimental, Centro de Pesquisas Gonçalo Moniz-Fiocruz, Rua Valdemar Falcão 121, 40295-001 Salvador, BA, Brasil

The main clinical forms of Chagas disease (acute, indeterminate and chronic cardiac) present strong evidences for the participation of the immune system on pathogenesis. Although parasite multiplication is evident during acute infection, the intense acute myocarditis of this phase exhibits clear ultrastructural signs of cell-mediated immune damage, inflicted to parasitized and non-parasitized myocardiocytes and to the endothelium of myocardial capillaries (microangiopathy). Inflammation subsides almost completely when immunity decreases parasite load and suppressor factors modulate host reaction, but inflammation does not disappear when the disease enters the indeterminate phase. Inflammation becomes mild and focal and undergoes cyclic changes leading to complete resolution. However, the process is maintained because the disappearance of old focal lesions is balanced by the upsurge of new ones. This equilibrium allows for prolonged host survival in the absence of symptoms or signs of disease. The chronic cardiac form is represented by a delayed-type, cell-mediated diffuse myocarditis, that probably ensues when the suppressive mechanisms, operative during the indeterminate phase, become defaulted. The mechanism responsible for the transition from the indeterminate to the cardiac form, is poorly understood.

Key words: Trypanosoma cruzi - immunopathology - myocarditis

The major aspects of the pathogenesis of Chagas disease remain poorly understood. Some crucial pathological findings strongly suggest the participation of immunological fators. Inflammatory lesions in the myocardium show no direct correlation with the presence of parasites, regardless the clinical stage of the disease. The acute myocarditis that follows primary infection with Trypanosoma cruzi, spontaneously subsides, after a period of two-three months in most cases, but does not disappear. In its place a mild focal myocarditis remains and may last for years without signs of cumulative damage. Suddenly or slowly, severe, diffuse, progressive and fatal chronic myocarditis ensues after a prolonged period of silent infection, in a small proportion of cases (about 30\%). This complex chain of events is unusual to be seen in other parasitic diseases. It has stimulated research on immunology and immunopathology of Chagas disease, but efforts are often hampered by lack of an adequate experimental model. Almost any mammal can be infected with T. cruzi. Acute infection (positive parasitemia in peripheral blood) can invariably be documented a week or more after inoculation. In some hosts infection will eventually

Fax: +55-71-359-4292

Received 9 June 1999

Accepted 9 August 1999 evolve toward spontaneous cure. Others will remain infected, without signs of disease (indeterminate form), but, different from the situation in man, none will develop progressive chronic myocarditis, with cardiomegaly, arrhytmias and signs of chronic cardiac failure following a prolonged time of silent infection. The dog is an exception. Young dogs usually develop severe acute disease when naturally or experimentally infected with $T$. cruzi (Andrade 1984). When acute manifestations abate, a period of latent infection follows and may last for life. Eventually, chronic myocarditis, accompanied by cardiomegaly, arrhytmias, dispnea, peripheral edema will appear, without any evidence of rapid resumption of parasite multiplication (Anselmi et al. 1966, Laranja \& Andrade 1980). Unfortunately, immunological data are scanty for this model, although a good amount of clinical and morphological data are avaliable. Most of the subject to be discussed in this chapter will be based on experimental studies made in dogs. This report will also be limited to heart involvement in Chagas disease. Lesions in other organs, especially involving the digestive tract, which may result in megaesophagus and megacolon, have been little explored as far as immunopathology is concerned.

\section{ACUTE PHASE MYOCARDITIS}

Initially, the diffuse and intense myocarditis associated with acute Chagas disease was considered directly related to parasite multiplication. The 
tissue forms of $T$. cruzi multiplied within cardiomyocytes and caused their rupture, liberating inflammatory mediators of several kinds. This was sufficient to explain the whole picture, since parasitism was easily observed in tissue sections. This contrasted to the situation with the chronic cardiac form, when parasites are rarely demonstrated by the usual techniques or even by a combination of them. Therefore, the pathogenesis of acute myocarditis was considered radically different from that of the chronic cardiac form. However, closer observations of acute cases revealed that, although parasites were present, the intensity of the inflammatory process did not always correlated with the overall presence of tissue forms of the parasites. Furthermore, destruction of nonparasitized cardiomyocytes was found to be an outstanding feature, and that seemed to require a more elaborated explanation.

Sequential examination of experimental material shows that the first changes related to $T$. cruzi infection appear around ruptured parasitized fibers. Presence of immuno-globulin and complement can be demonstrated in these focal lesions by immunofluorescence, revealing the early participation of humoral immune factors in pathogenesis (Silva et al. 1985). Initially focal reactions are seen scattered distributed throughout the myocardium a few days after experimental inoculation. This is soon followed by diffuse and more intense inflammation. When this happens, isolated necrosis of nonparasitized cardiomyocytes becomes more or less prominent. From then on, signs of cell-mediated immune damage can be ultrastructurally disclosed (Andrade et al. 1994). There is close adhesion of mononuclear cells (small and large granular lymphocytes, probably NK-cells and also macrophages) to cardiomyocyte membrane, with fusion of membrane at focal points, accompanied by focal disruption of $\mathrm{T}$ tubules, sarcoplasmic reticulum, myofibrils, mitochondria and even intercallated disks (Fig. 1). Damage to the cardiocyte sometimes is multifocal, and leads to lytic or coagulative necrosis of large segments of the cardiomyocytes or even of their entire length. Cells in close proximity to the damaged ones usually

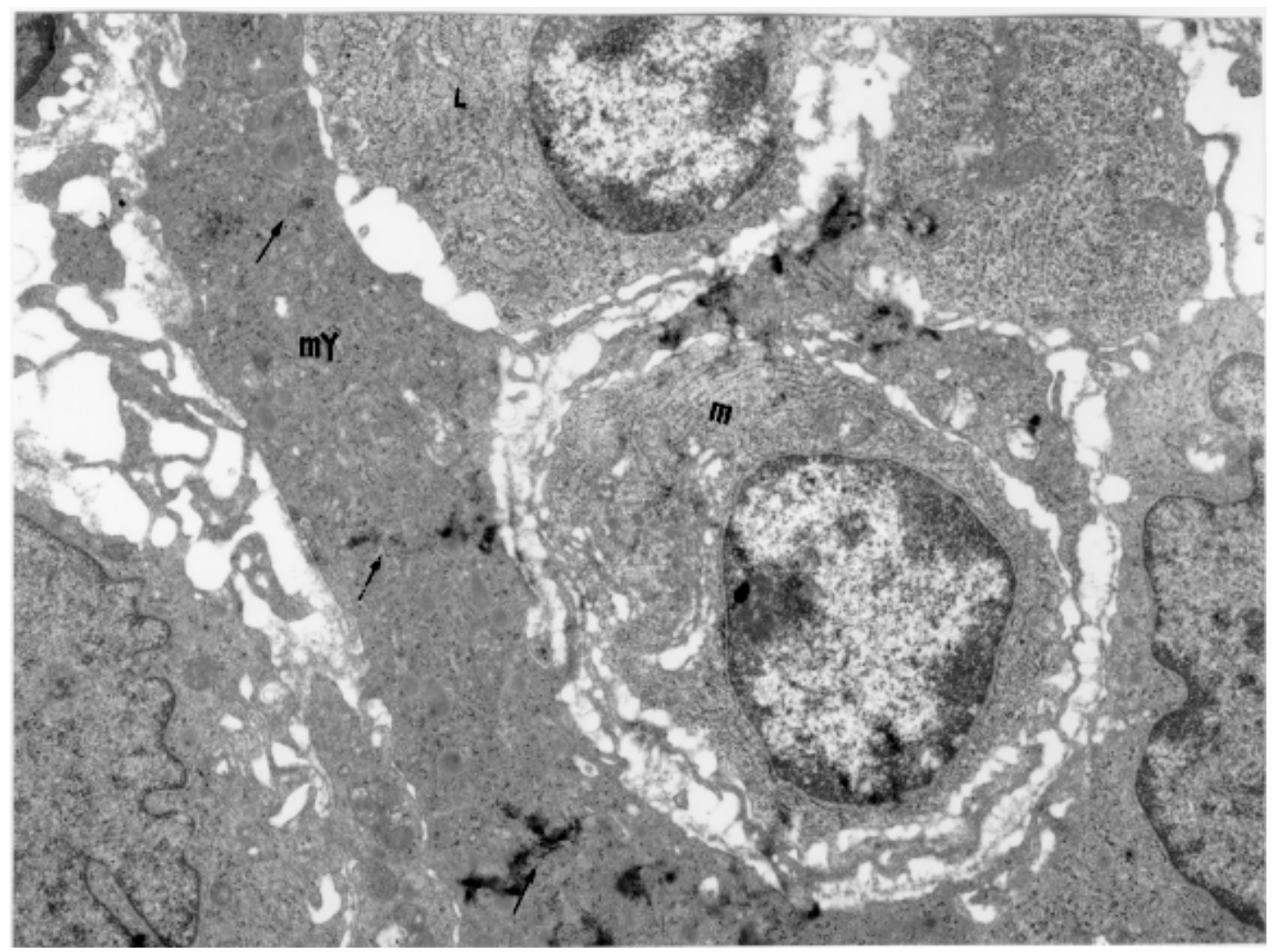

Fig. 1: acute Chagas myocarditis. A dissociated myofiber (My) appears undergoing coagulative necrosis in the middle of lymphocytes (L) and macrophages (M). There are points of contact and fusion between the membranes of the leukocytes and the myocell. Fragmentation of scalariform disks is evident (arrows). Electron micrograph, X5,000. 
appear entirely preserved. Possible causes for these changes have been suggested: (a) immunological injury after adsorption of $T$. cruzi antigens on nonparasitized cells (Ribeiro dos Santos \& Hudson 1980); (b) ischemic injury due to platelet aggregation and obstruction of myocardial capillaries (Rossi et al. 1984, Tanowitz et al. 1990); (c) direct or antibody-mediated cytotoxic damage by inflammatory and immune effector cells, including lymphocytes, neutrophils, eosinophils, macrophages and mast cells (Lopes et al. 1977, Tafuri et al. 1983, Cabral 1988, Molina \& Kierszenbuam 1989, Rossi 1990).

Besides these destructive changes of myocytes, a microangiopathy is also observed. It consists of myocardial capillary involvement, following close contact between lymphocytes or macrophages to the endothelial cells (Andrade et al. 1994). In the contact points there occur membrane fusion and increased pinocytosis, tumefaction, vacuolation and cytoplasmic disruption of endothelial cells, associated or not with platelet aggregation and fibrin microthrombi (Fig. 2). The role of a vascular factor in acute Chagas myocarditis has been emphasized, especially by investigators who observed platelet thrombi within myocardial capillaries of mice (Rossi et al. 1984, Tanowitz et al. 1990). However, the ultrastructural signs of cytotoxic damage to the myocytes seen in the canine model far exceeded those indicative of ischemic injury (Andrade 1984). On the other hand, microangiopathy appears as an important clue suggesting the participation of cytokines in acute Chagas myocarditis. Similar vascular changes have been observed in patients dying of the so-called "leaky syndrome" after being treated with large doses of interleukin-2 (Cotran et al. 1987). Experimentally, rats treated either with recombinant interleukin-2, interleukin-1 and tumor necrosis factors also exhibited similar myocardial microangiopathy (Yi \& Ulich 1992, Zhang et al. 1993). Recent studies have demonstrated that cytokines associated with CD4 response of the Th1 type, can be enhanced by the administration of IL-12, which results in the production of INF- $\gamma$, IL2 and TNF- $\alpha$, causing reduction in parasitemic levels of infected animals (Silva et al. 1995,

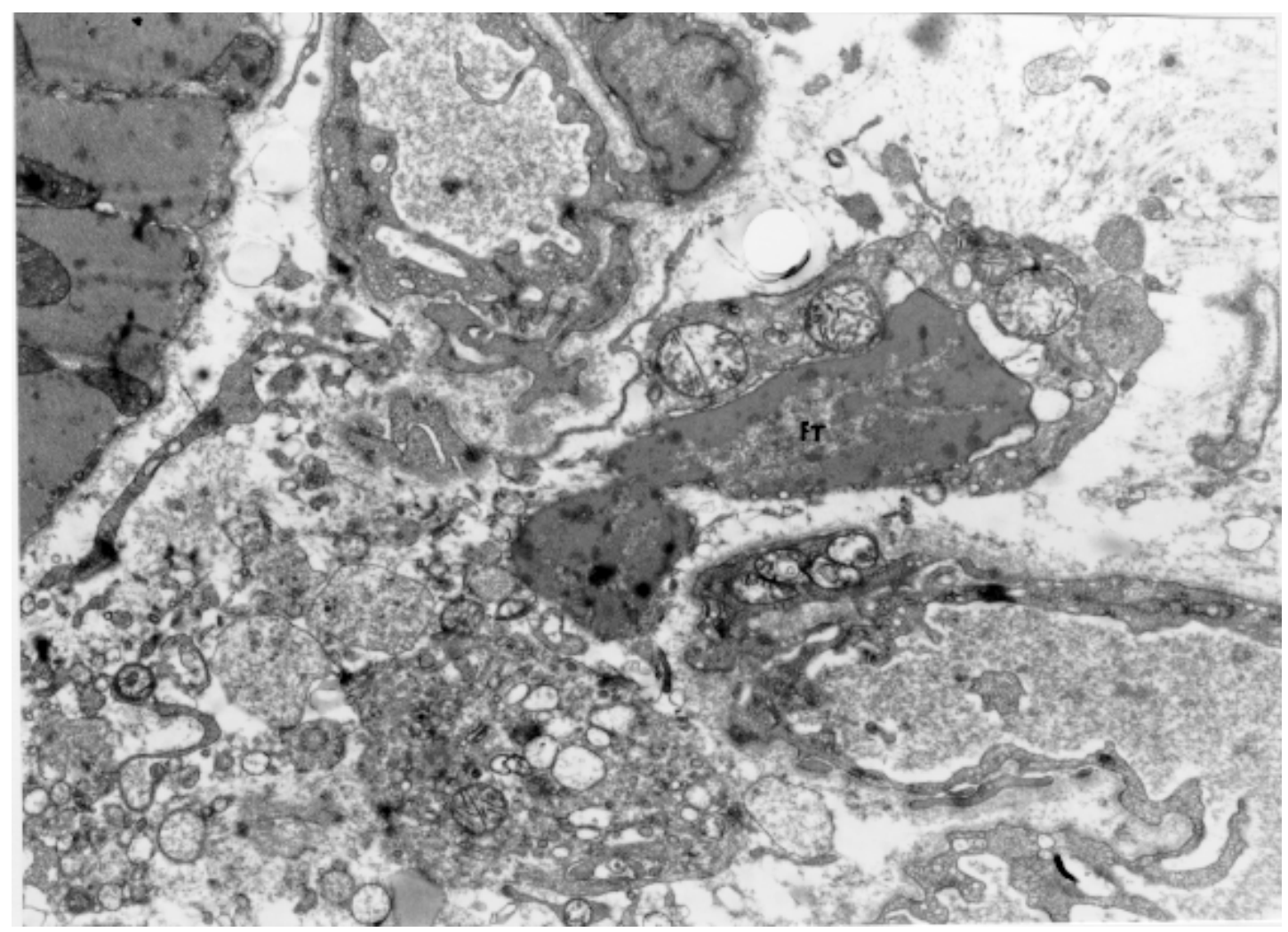

Fig. 2: microangiopathy in acute Chagas myocarditis. A myocardial capillary appears with its lumen occluded by fibrinous thrombus $(\mathrm{Ft})$, while others are dilated and exhibit pinocytosis of endothelial cells. Electron micrograph. X5,000 
Abrahamsohn \& Coffman 1996, Cardillo et at. 1996, Hunter et al. 1996). Probably this mechanism of protection, when overwhelming, would contribute to capillary and other myocardial changes during the course of acute Chagas disease.

\section{IMMUNOLOGICAL MODULATION}

There are two basic host reactions to T. cruzi, which are represented by focal and diffuse inflammation. Focal reaction is parasite-mediated. It occurs anywhere the parasite enters host cells and then multiplies, causing cell-rupture. Focal heart lesions, observed in human tissue in which parasite could not be demonstrated in routine histological sections, revealed the presence of parasite antigen by immunohistochemistry (Higuchi et al. 1993) or its genomic segments by PCR technique (Jones et al. 1993), which is in keeping with the idea that focal inflammatory reactions are parasiteinduced.

The heart may present both types of reactions. Diffuse inflammation is not directly parasite related. It occurs during the acute and chronic cardiac forms, while mild focal inflammation is the hallmark of the indeterminate form of the disease.

All other organs exhibit only focal reactions following parasitized-cell rupture, regardless the type of reaction present in the heart. This simple observation reveals that some important pathogenic factors of chagasic myocarditis are related to the heart itself. Also, by observing the cardiac histopathology one can follow the changes suggestive of immunological modulation during the several clinical stages of Chagas disease. The complete picture regarding what happen when diffuse inflammation of the acute phase subsides and turns into a mild focal myocarditis, is poorly understood. The same is true for the transition of focal myocarditis of the indeterminate form toward the diffuse and fibrosing chronic myocarditis of the cardiac form. Of course immunity factors, both humoral and cellular, contribute to decreasing parasite load. When cytokines patterns were investigated, transition from the acute form to the indeterminate form was identified in infected children as a CD4-Th1 response changing into a Th0 pattern, with expression of both interferon-gamma and IL-4 (Smudio et al. 1998). There are evidences that immunossupression plays a role in diminishing and modifying the character of the inflammatory reaction ellicited by $T$. cruzi (Tarleton 1998). Depressed delayed skin reaction to parasite antigens and in-vitro demonstration of inhibition of IL2 lymphocyte production have been reported in mice. Immunossupresed individuals with latent $T$. cruzi infection, especially those affect by Aids, are seen to present acute exacerbation of the infection (Tarleton 1993, Rocha et al. 1994).

\section{THE INDETERMINATE FORM}

The indeterminate phase of Chagas disease is defined as the prolonged clinically silent period that follows the phase of acute primary infection with $T$. cruzi. The individuals present serological and/or parasitological evidences of infection, but remain asymptomatic and do not exhibit electrocardiographic signs of heart involvement, nor Xrays abnormalities of the digestive tract.

Microscopically, infected individuals at the indeterminate form of Chagas disease reveal mild focal myocarditis when their hearts are examined following biopsies (Mady et al. 1984, Palacios-Pru et al. 1989) or autopsies, that latter material being available after suicidal or accidental deaths (Lopes et al. 1975, 1981). However, longitudinal clinical studies have demonstrated that subjects presenting the indeterminate form tend to remain asymptomatic for prolonged time, and thus prognosis can be considered good. This also indicate that lesions of mild focal myocarditis are not cumulative.

Recent ultrastructural studies have demonstrated that the inflammatory cells comprise lymphocytes, plasma cells, macrophages, and a few polymorphonuclears and mast cells (Andrade et al. 1997). The inflammatory cells are accumulated in focal areas of the interstitial tissue of the myocardium, and do not establish cell-to-cell contact with myocardiocytes and do not invade or destroy them, as occurs during acute disease (Fig. 3). In some of these focal lesions there are evidences of extracellular matrix degradation (dissolution, fragmentation, and thickening of both collagen and elastic fibers), plus signs indicative of apoptosis (nuclear condensation and fragmentation, formation of apoptotic bodies) (Fig. 4). These are changes indicative of a cyclic mechanism of evolution for the focal inflammatory lesions (Andrade et al. 1997). As new lesions appear, the older ones are gradually removed by degradation of excess extracellular matrix (fibrolysis), and by resorption of inflammatory cells (apoptosis). Apoptosis of inflammatory cells is so common that can be considered non-specific, but in focal myocarditis of Chagas disease it occurred simultaneously in almost all cells of one single focus (Fig. 5). Probably, the formation of new lesions is balanced by the removal of older ones, thus allowing for prolonged host survival, almost without clinical manifestations. Of course manifestations may appear in the case focal lesions happen to involve strategic structures of the heart, such as the conducting system or the intrinsic autonomic nervous system. 


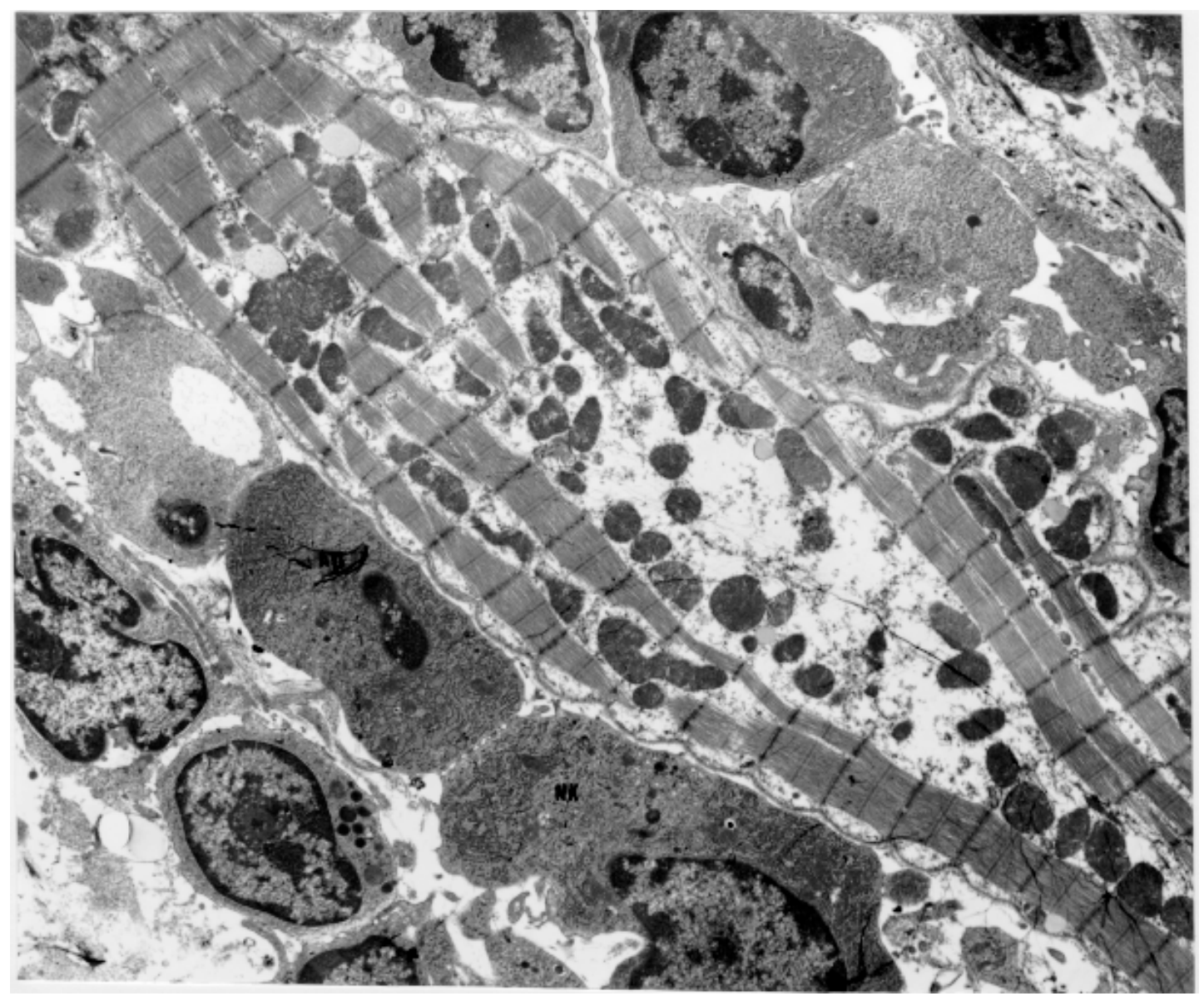

Fig. 3: indeterminate Chagas disease in the dog. Inflammatory cells are present in interstitial tissue, but do not make membrane to membrane contact with myocardiocytes. Some cells are large granular lymphocytes (NK cells). Others exhibit apoptosis (Ap). Normal myocardiocytes appear at the center of the picture. Electron micrograp. X3,000.

Transition to chronic cardiac form probably occurs through disappearance of, or interference with, suppressive factors. Therefore, both parasites and heart tissue appear to be important to explain diffuse and progressive inflammatory lesions of the cardiac form, since parasites outside the heart will continue to induce focal reactions only (Barbosa $\&$ Andrade 1984). The factors responsible for the transition from the indeterminate to the chronic, progressive stage of Chagas disease remain to be elucidated. This transition, in which the suppression of cell-mediated immune responses ceases to occur, seems to be related to reactivation of the inflammation. The inflammatory reaction of the chronic phase of Chagas disease in humans has been recently characterized as consisting mainly of cytotoxic CD8 ${ }^{+}$T-lymphocytes (Tostes et al. 1994). These cells were seen to express the Gramzyme A cytotoxic factor (Reis et al. 1993). It has been now a consensus that $\mathrm{CD} 8^{+}$lympho- cytes are the main T-cell type responsible for immune activation in chronic chagasic myocarditis (Kumar \& Tarleton 1998). These cells are activated, through Class I MHC molecules, by macrophages containing remnants of $T$. cruzi. The absence of a $\mathrm{CD}^{+} \mathrm{T}$-cell response in the presence of $T$. cruzi antigens suggests that the presentation of these antigens through Class II MHC molecules is inhibited. However, other evidence suggests that the depletion of $\mathrm{CD}^{+}$lymphocytes in the chronic phase of Chagas disease is related to selective apoptosis of these cells (Lopes et al. 1995). In the mouse model of chronic Chagasic cardiomyopathy, stimulation of $\mathrm{T}$ cells results in apoptosis of $\mathrm{CD} 4^{+}$cells but not of $\mathrm{CD}^{+}$cells (DosReis et al. 1995) Taken together, the morphologic and immunologic observations reviewed above support the concept that the indeterminate phase of Chagas disease represents a state of host-parasite equilibrium rather than of progressive chronic myocardial damage. 


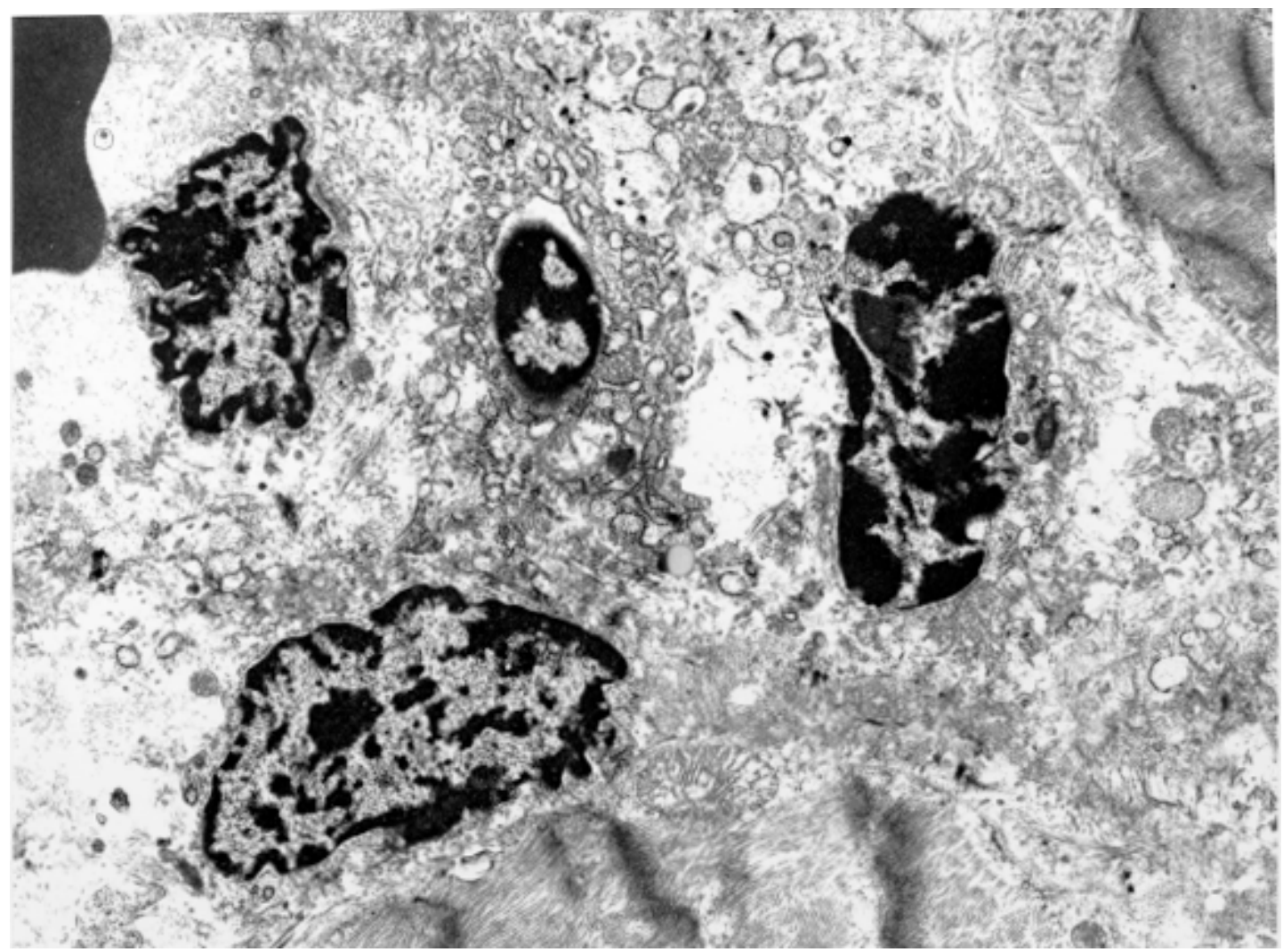

Fig. 4: heart of dog with indeterminated Chagas disease. Chromatic nuclear materials (DNA) belonging to four disintegrating cells, probably cardiomyocytes, show different degree of condensation and fragmentation (apoptosis). Electron micrograph, X5,000.

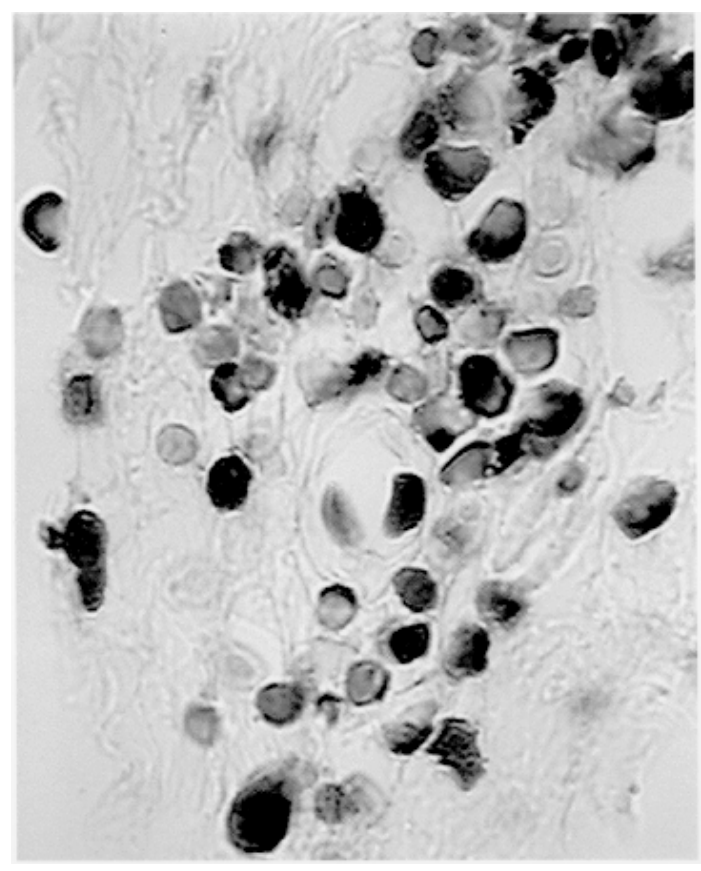

Fig. 5: positive apoptosis test of almost all inflammatory cells present in a focal myocardial reaction, in a dog with the indeterminate form of Chagas disease. Apoptag kit, X150.

\section{THE CHRONIC CARDIAC FORM}

The phase of chronic, progressive myocarditis and congestive heart failure which are associated with myocardial hypertrophy, myocyte degeneration, severe interstitial fibrosis and thickening of the basement membranes characterize the pathological picture of the chronic cardiac form of Chagas disease. One can assume that this form originates from the indeterminate stage of latent infection, in $30 \%$ of the cases in man, and much less for the dog. Some important points usually pass unnoticed. A progressive, destructive and reparative process appears in the heart, previously affected during a long time by mild diffuse myocarditis. Although rarely, parasites can also be found in several other organs always accompanied by focal inflammation, a situation entirely similar to that seen in the heart during the indeterminate stage. Except for such focal and rare microscopic parasite-related changes, no other abnormalities are apparent outside of the heart during the chronic cardiac form, except those derived from chronic passive congestion and thrombo-embolic phenomena. No evident modification, from the status of the indeterminate phase, occurs regarding para- 
sitism. Also, there are no definite changes regarding serum antibodies. There have been some attempts to investigate the behavior of mononuclear cells in peripheral blood, with the result that some suppressor cells can be differentially stimulated with anti-idiotypic antibodies (Ouaissi et al. 1988, Gazzineli et al. 1988). Also, lymphocytes directly isolated from the heart of patients with either the indeterminate or the cardiac forms of Chagas disease have exhibited different patterns of reactivity when in the presence of a particular myocardial epitope (Cunha Neto et al. 1995).

Experimental reproduction of the transition from the period of silent infection to chronic progressive myocarditis has been achieved with the canine model (Andrade et al. 1987). Animals with known acute infection at early age, and with prolonged silent period of infection, with no electrocardiographic alterations, were treated with low doses of cyclophosphamide. This procedure has been assumed to exacerbate cell-mediated lesions, probably by selectively destroying suppressor Tlymphocytes, their precursor cells, or other elements in the host-immune supressor network (Turk et al. 1972, Schwartz et al. 1978, Colley et al. 1979, Liew \& Russel 1983).

In contrast to non-treated dogs, that remained with mild focal myocarditis, all treated animals exhibited intense and diffuse myocarditis (Fig. 6). Destruction of isolated myocells was extensive throughout the contractile myocardium and the conduction system. Mononuclear cells were seen at the periphery and in the interior of disintegrating myocardiocytes. Tissue forms of T. cruzi were not detected in histological section although exhaustively searched. Parasitemia in peripheral blood was always negative.

The mechanism of cell-mediated myocardial damage remains to be elucidated. The suggestion for an auto-immune process has been frequently presented, but has not been proved (Kierszembaum 1986). A strong support in favor of an auto-immune mechanism for Chagas myocarditis came from experiments with transplanted neonatal hearts into the external ear of isogenic mice (Ribeiro dos Santos et al. 1992). While the transplants remained viable for a long time, when into the ear of normal receptors, they were rejected if the receptor was chronically infected with $T$. cruzi. Effector cells were identified as CD4 lymphocytes. However, recent data from Tarleton et al. (1997) contradict these findings. They failed to observe rejection of transplanted neonatal hearts placed into chronically infected mice. Severe inflammation occurred only when $T$. cruzi was directly injected into the transplant, showing that the parasite, and not an

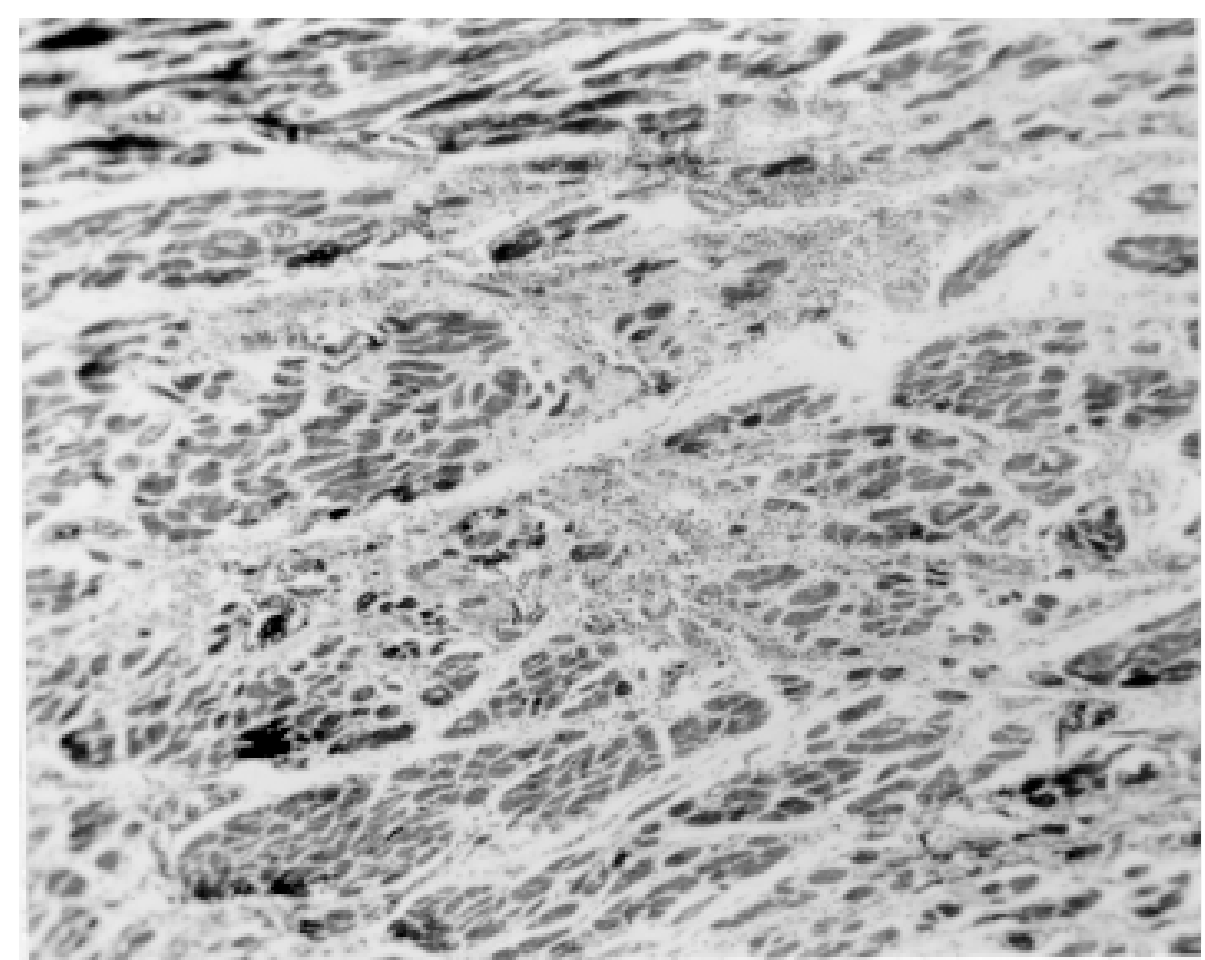

Fig. 6: heart of a dog with prolonged silent Trypanosoma cruzi infection after being treated with low dose cyclophosphamide. A chronic diffuse myocarditis, with some degree of fibrosis is now apparent. H \& E, X100. 
auto-immune process, was responsible for the effect observed in experiments with transplanted neonatal hearts.

The auto-immune theory is supported by the lack of correlation between parasitism and chronic myocarditis. However, the great age variation of the patients at the onset of clinical manifestations, the lack of exacerbations and remissions, the absence of typical auto-antibodies at high and constant levels, the lack of involvement of other organs, are not in keeping with an auto-immune process. Some investigators have documented the identity of epitopes present in the parasite and myocardium (Sadigursky et al. 1982). These crossreacting molecules could attract the destructive power of the sensitized immune system. Similarly, the same could occur if parasite antigens happen to be expressed in the myocyte membrane, or be adsorbed onto it (Ribeiro dos Santos \& Hudson 1909). There are several other suggestions to explain myocardial damage in T. cruzi infection, all of them in needing of further research. Some data refer to the idiotype/anti-idiotype network. When generating antibodies against anti-T. cruzi globulins, the host organism would be in effect producing antibodies that would have the same configuration as that of the parasite. These antibodies could therefore, either directly react with or activate immune cells against receptors present in the cardiomyocyte membranes. One such cross reacting antigen found in man was represented by an enzyme, acetyl-cholinesterase. The anti-idiotype antibody against this epitope was found to be more frequent in the sera of patients with the cardiac form of Chagas disease than in those of the indeterminate form (Quaissi et al. 1988). Other differences regarding anti-idiotypic antibodies have been registered for the latent and active chronic forms of the disease. These findings are not only interesting for the supporters of the theory of auto-immunity, but points toward the existence of a process of modulation or repression/des-repression in Chagas disease pathogenesis.

\section{REFERENCES}

Abrahamsohn IA, Coffman RL 1996. Trypanosoma cruzi: Il-10, TNF, INF- $\gamma$, and Il-12 regulate innate and acquired immunity to infection. Exp Parasitol 84: 231-244.

Andrade ZA 1984 The canine model of Chagas disease. Mem Inst Oswaldo Cruz 79: 77-83.

Andrade ZA, Andrade SG, Correa, R, Sadigursky M, Ferrans VJ 1994. Myocardial changes in acute Trypanosoma cruzi infection. Ultrastructural evidence of immune damage and the role of microangiopathy. Am J Pathol 144: 1403-1411.

Andrade ZA, Andrade SG, Sadigursky M 1987. Enhancement of chronic Trypanosoma cruzi myocardi- tis in dogs treated with low doses of cyclophosphamide. Am J Pathol 127: 467-473.

Andrade ZA, Andrade SG, Sadigursky M, Wenthold Jr RJ, Hilbert SL, Ferrans VJ 1997. The indeterminate phase of Chagas disease: ultrastructural characterization of cardiac changes in the canine model. Am J Trop Med Hyg 57: 328-336.

Anselmi A, Pifano F, Suarez JA, Gurdiel O 1966. Myocardiopathy in Chagas disease. I. Comparative study of pathologic findings in chronic human and experimental Chagas myocarditis. Am Heart J 72: 469-481.

Barbosa Jr AA, Andrade ZA 1984. Identificação do Trypanososoma cruzi nos tecidos extracardíacos de portadores de miocardite crônica chagásica. Rev Soc Bras Med Trop 17: 123-126.

Cabral HRA 1988. Mastocitos en contacto com fibras musculares cardíacas en miocardio de pacientes com cardiopatia de Chagas severa. Prensa Med Argent 75: 490-496.

Cardillo F, Voltarelli JC, Reed SG, Silva JS 1996. Regulation of Trypanosoma cruzi infection in mice by gamma interferon and interleukin 10: role of NK cells. Infect Immun 64: 128-134.

Colley DG, Lewis FA, Todd CW 1979. Adoptive suppression of granuloma formation by $\mathrm{T}$ lymphocytes and by lymphoid cells sensitive to cyclophosphamide. Cell Immunol 46: 192-200.

Cotran RS, Pober JS, Giambrone Jr MA, Springer TA, Wiebke EA, Gaspari AA, Rosenberg SA, Lotze MT 1987. Endothelial activation during interleukin 2 immunotherapy. A possible mechanism for the vascular leaky syndrome. J Immunol 139: 1883-1888

Cunha-Neto E, Duranti M, Gruber A, Zingales B, Messias I, Stolf N, Bellotti G, Patarroyo ME, Pilleggi F, Kalil J 1995. Autoimmunity in Chagas disease cardiopathy: biological relevance of a cardiac myosin-specific epitope crossreactive to an immunodominant Trypanosoma cruzi antigen. Proc Natl Acad Sci USA 92: 3541-3545.

DosReis GA, Fonseca MEF, Lopes MF 1995. Programmed T-cell death in experimental Chagas disease. Parasitol Today 11: 390-394.

Gazzinelli RT, Morato MJ, Nunes RM, Cançado JR, Brener Z, Gazzinelli G 1988. Idiotype stimulation of T Iymphocytes from Trypanosoma cruzi-infected patients. J Immunol 140: 3167-3172.

Higuchi ML, Brito T, Reis M, Barbosa A, Bellotti G, Pereira Barretto AC, Pileggi F 1993. Correlation between T. cruzi parasitism and myocardial inflammatory infiltrate in human chronic chagasic myocarditis. Light microscopy and immunohistochemical findings. Cardiovasc Pathol 2: 101-106.

Higuchi M, Reis M, Gutierrez P, Aiello V 1995. Myocardial T. cruzi antigens induces increases of CD8+ but not of CD4+ T cell numbers in human chronic Chagas cardiopathy. Circulation 92 (Suppl. 1): 1470.

Hunter CA, Slifer T, Araujo F 1996. Interleukin-12 mediated resistance to Trypanosoma cruzi is dependent on tumor necrosis factor alpha and gamma interferon. Infect Immun 64: 2381-2386. 
Jones EM, Colley DG, Tostes S, Lopes ER, Vnencak-Jones CL, McCurley TL 1993. Amplification of a Trypanosoma cruzi DNA sequence from inflammatory lesions in human chagasic cardiomyopathy. Am J Trop Med Hyg 48: 348-357.

Kierszembaum F 1986. Autoimmunity in Chagas disease. J Parasitol 72: 201-211.

Kumar S, Tarleton RL 1998. The relative contribution of antibody production and CD8+T cell function to immune control of Trypanosoma cruzi. Parasite Immunol 20: 207-216.

Laranja FS, Andrade ZA 1980. Forma crônica cardíaca da doença de Chagas no cão. Arq Bras Cardiol 35: 377-380.

Liew FY, Russel SM 1983. Inhibition of pathogenic effect of effector T cells by specific suppressor T cells during influenza virus infection in mice. Nature 304 : 541-543.

Lopes ER, Chapadeiro E, Almeida HO, Rocha A 1975. Contribuição ao estudo da anatomia patológica dos corações de chagásicos falecidos subitamente. Rev Soc Bras Med Trop 9: 269-282.

Lopes ER, Chapadeiro E, Andrade ZA 1981. Anatomia patológica do coração em chagásicos assintomáticos falecidos de modo violento. Mem Inst Oswaldo Cruz 76: 189-197.

Lopes ER, Tafuri WL, Bogliolo L, Almeida HO Chapadeiro E 1977. Miocardite chagásica aguda humana (ganglionite subpicárdica; agressão a fibra cardiaca por linfócitos; relação entre amastigotas e a fibra muscular). Rev Inst Med Trop São Paulo 19: 301-309.

Lopes MF, Veiga VF, Santos AR, Fonseca ME, DosReis GA 1995. Activation-Induced CD4+ T cell death by apoptosis in experimental Chagas disease. $J$ Immunol 154: 744-752.

Mady C, Pereira-Barretto AC, lanni BM, Lopes EA, Pileggi F 1984. Right ventricular endomyocardial biopsy in undetermined form of Chagas disease. Angiology 35: 755-759.

Molina HA, Kierszenbaum F 1989. Eosinophil activation in acute and chronic chagasic myocardial lesions and deposition of toxic eosinophil granule proteins on heart myofibers. J Parasitol 75: 129-133.

Morgan J, Dias JC, Gontijo ED, Oliveira LB, Oliveira RC, Colley DG, Powell MR 1996. Anti-Trypanosoma cruzi antibody isotype profiles in patients with different clinical manifestations of Chagas disease. Am J Trop Med Hyg 55: 355-359.

Ouaissi A, Cornette J, Velge P, Capron A 1988. Identification of anti-acetylcholinesterase and anti-idiotype antibodies in human and experimental Chagas disease: pathological implications. Eur J Immunol 18: 1889-1894.

Palacios-Pru E, Carrasco H, Scorza C, Espinoza R 1989. Ultrastructural characteristics of different stages of human chagasic myocarditis. Am J Trop Med Hyg 41: 29-40.

Reis DA, Jones EM, Tostes Jr S, Lopes ER, Gazzinelli G, Colley DG, McCurley TL 1993. Characterization of inflammatory infiltrates in chronic chagasic myocardial lesions: presence of tumor necrosis fac- tor- $\alpha+$ cells and dominance of granzyme A+, CD8+ lymphocytes. Am J Trop Med Hyg 48: 637-644.

Ribeiro dos Santos R, Hudson L 1980. Trypanosoma cruzi: binding of parasite antigen to mammalian cells. Parasite Immunol 2: 1-10.

Ribeiro dos Santos RR, Rossi M, Laus JL, Silva JS, Savino W, Mengel J 1992. Anti-CD4 abrogates rejection and reestablishes long-term tolerance to syngeneic newborn heartys grafted in mice chronically infected with Trypanosoma cruzi. J Exp Med 175: 29-39.

Rocha A, Meneses ACO, Silva AM, Ferreira MS, Nishioka AS, Burgarelli MKN, Almeida E, Turcato Jr G, Metze K, Lopes ER 1994. Pathology of patients with Chagas disease and acquired immunodeficiency syndrome. Am J Trop Med Hyg 50: 261268.

Rossi MA 1990. Myocardial damage in Trypanosoma cruzi myocarditis: a role for macrophages. Can J Cardiol 6: 293-298.

Rossi MA, Gonçalves S, Ribeiro dos Santos R 1984. Experimental Trypanosoma cruzi myocardiopathy in Balb/c mice: the potential role of intravascular platelet aggregation in its genesis. Am J Pathol 114: 209-216.

Sadigursky M, Acosta AM, Santos Buch CA 1982. Muscle sarcoplasmic reticulum antigen shared by a Trypanosoma cruzi clone. Am J Trop Med Hyg 31: 934-941.

Schwartz A. Askenase PW, Gershon RK 1978. Regulation of delayed-type hypersensitivity reactions by cyclophosphamide-sensitive T cells. J Immunol 121: 1573-1577.

Silva JC, Pirmez C, Morgado MG, GalvãoB 1985. Immunopathological aspects of experimental Trypanosoma cruzi infection: correlation of immune complexes and other serological features with muscle lesions during the infection. Parasite Immunol 7: 457-466.

Silva JS, Vespa GNR, Cardoso MAG, Aliberti JCS, Cunha FO 1995. Tumor necrosis factor alpha mediate resistance to Trypanosoma cruzi infection in mice by inducing nitric oxide production in infected gamma interferon-activated macrophages. Infect Immun 63: 4862-4867.

Smudio M, James SM, Cabral M, Martinez J, Arias AR, James MA 1998. Cytokine responses in Trypanosoma cruzi -infected children in Paraguay. Am J Trop Med Hyg 58: 119-121.

Tafuri WL, Lopes ER, Chapadeiro E, Miziara HL, Santos BG, Raso P 1993. Miocardite chagásica humana: provável agressão à célula cardíaca pelo granulócito eosinófilo. Rev Soc Bras Med Trop 16: 122-124.

Tanowitz HB, Burns ER, Shina AK, Khan NN, Morris AS, Factor SM, Hatcher VB, Bilezikian JP, Baum SG, Wittner M 1990. Enhanced platelet adherence and aggregation in Chagas disease: a potential pathogenic mechanism to cardiomyopathy. Am J Trop Med Hyg 43: 274-281.

Tarleton RL 1993. Pathology of American trypanosomiasis, p. 64-85. In KS Warren, Immunology and Molecular Biology of Parasitic Diseases, 3rd Edi- 
tion, Blackwell Scientific Publications, Boston.

Tarleton RL 1998. Trypanosoma cruzi-induced suppression of Il-2 production. II Evidence for a role for suppressor cells. J Immunol 140: 2769-2773.

Tarleton RL, Zhang L, Downs MO 1997. Rejection of neonatal heart transplants in experimental Chagas disease is a parasite-specific response to infected host tissue. Proc Natl Acad Sci USA 199: 3932-3937.

Tostes Jr S, Lopes ER, Pereira FEL, Chapadeiro E 1994. Miocardite chagásica crônica humana: estudo quantitativo dos linfócitos CD4+ e dos CD8+ no exsudato inflamatório. Rev Soc Bras Med Trop 27:
127-134.

Turk JL, Parker D, Poulter LW, 1972. Functional aspects of the selective depletion of Iymphoid tissue by cyclophosphamide. Immunology 23: 493-501.

Yi ES, Ulich TR 1992. Endotoxin, interleukin-1, and tumor necrosis factor cause neutrophil-dependent microvascular leakage in post capillary venules. $A m$ J Pathol 140: 656-663.

Zhang J, Yu ZX, Hilbert ST, Yamaguchi M, Chadwick DP, HermanEH, Ferrans VJ 1993. Carditoxicity of human recombinant interleukin-2 in rats: a morphological study. Circulation 87: 13-40. 